\title{
CROP AGRICULTURE OF CHITTAGONG HILL TRACTS: REVIEWING ITS MANAGEMENT, PERFORMANCE, VULNERABILITY AND DEVELOPMENT MODEL
}

\author{
Md. Iqbal Hossain ${ }^{1}$; Zabid Al Riyadh ${ }^{1}$; Jannatul Ferdousi ${ }^{2 *}$; \\ Md. Abiar Rahman ${ }^{1}$ and Satya Ranjan Saha ${ }^{1}$ \\ ${ }^{1}$ Department of Agroforestry and Environment, Bangabandhu Sheikh Mujibur \\ Rahman Agricultural University, Gazipur, Bangladesh. \\ ${ }^{2}$ Department of Horticulture, Sylhet Agricultural University, Sylhet, Bangladesh. \\ *Corresponding Author
}

DOI: https://doi.org/10.51193/IJAER.2020.6505

\begin{abstract}
This paper presents the crop production systems with their impacts on environment in Chittagong Hill Tracts (CHTs) of Bangladesh. Boro-fallow-T. aman, fallow-fallow-T. aman and fallow-aus+non-rice (jhum) are the major cropping patterns in CHTs. Crop agriculture in hill is mainly divided into two systems i.e. plain land plough agriculture and non-plough slope agriculture. In valley and foothill, irrigated seasonal and annual crops are cultivated extensively. In hilly slope; shifting cultivation, horticultural plantation, agroforestry and mixed fruit gardening are practiced in Bangladesh. Shifting cultivation (jhum) is a traditional system being practiced in the CHTs by the tribal communities. An increasing trend of fruit cultivation and production is observed in CHTs. Agroforestry and perennial fruit gardening showed lucrative economic benefits with environmental stability in this region. Extensive jhum practice creating a dilemma in conserving nature and food production. Soil erosion is extensive in CHTs due to shifting cultivation and monocropping systems. Tobacco and, slash and burn method of cultivation are very destructive to land and forest ecosystems. Sustainable alternate land use of jhum farming including multistorey agroforestry and multistrata fruit orchard have evolved in some areas of CHTs. Although alternate land use practices started, extensive expansion should be ensured rapidly for the development of agricultural production and environmental conservation.
\end{abstract}


International Journal of Agriculture and Environmental Research

ISSN: $2455-6939$

Volume: 06, Issue: 05 "September-October 2020"

Keywords: Hill slope, Plough agriculture, Shifting cultivation, Agroforestry, Fruit orchard, Environment

\section{INTRODUCTION}

Chittagong Hill Tracts (CHTs) comprise 10\% of country's landmass, is located at southeastern parts of Bangladesh characterized by alternating beds of little-consolidated sands and shale providing a basis for the formation of complex mixtures of deep and shallow soils (Zakaria and Majumder, 2019; Hossain, 2011). Bandarban, Khagrachari and Rangamati districts are called together Chittagong Hill Tracts. The CHTs comprising $70 \%$ of the hilly areas of Bangladesh and covers 13,184 $\mathrm{km}^{2}$, of which $90 \%$ are sloping lands (Hossain et al., 2017). The area is mild to very steep ranging from $15 \%$ to over $70 \%$ slope, often breaking or ending in cliffs (SRDI, 2018). High hills ranged from 200-1000 $\mathrm{m}$ and lower hills from 15-200 $\mathrm{m}$ above the mean sea level (Hossain et al., 2017).

Agriculture is the main source of livelihood of the majority of CHTs dwellers. Agricultural activities include ploughing lands, shifting cultivation, fruit gardening, paid wage labor, timber production, livestock and poultry rearing, and free fishing. More than 35 crop species are cultivated annually in CHTs (Ahammad and Stacey, 2016). Crop agriculture including fruits and trees provide both subsistence needs and cash incomes of both Bengali and ethnic communities in hilly areas. Agriculture in the hilly area is greatly rainfed. Hills are highly susceptible to erosion and difficult to irrigate. The monsoon rainfall is very high, more than $2200 \mathrm{~mm}$ annually. Valleys and floodplains of the CHT are suitable for plough agriculture using mainly for cultivation of rice, maize, tobacco, potato, cotton, papaya, sugarcane, pineapple, turmeric, ginger, aroid and others vegetables (Ahammad and Stacey, 2016). The hill slopes are suitable for growing a number of high value fruits such as banana, pineapple, papaya, mango, litchi, jackfruit, orange, guava, dragon fruit and lemons. The CHTs region is one of the richest fruit production regions in Bangladesh. At least 25\% of households of CHTs produce banana in their annual farming plots and home yards (Khan et al., 2012). Distinctive climatic conditions of CHTs provides a great diversity and variety for fruit production, and orchard fruit production system comprises the largest fruit sector of Bangladesh (Dewan et al., 2015). Tree based crop production systems either with fruit or timber plantations have increased in CHTs which are more economically attractive and environmentally sound (Bala et al., 2013). There is tremendous potential for growing high value crops such as fruit, vegetables, medicinal plants and aromatic plants under agroforestry system in hilly areas (Rasul and Tripura, 2016).

Shifting cultivation (Jhum) is a form of customs and rituals of tribal which governs hill agriculture in a cultural and sustainable way where land is cleared by controlled fire, used only for subsistence farming and then natural fallow phase employed long enough to be dominated by 
International Journal of Agriculture and Environmental Research

ISSN: 2455-6939

Volume: 06, Issue: 05 "September-October 2020"

woody vegetation (Bhagawati et al., 2015). Even though Jhum has considerably declined in recent years but still a dominant land-use system in the hilly terrain and has been practiced by local indigenous groups of CHTs for centuries (Khisa and Mohiuddin, 2015). Many studies on CHTs indicated that short-rotation in shifting cultivation for annual cropping has negative impacts on ultimate food production capacity of the lands and environment (Bala et al., 2010; Rahman et al., 2012; Rahman et al., 2014).

Crop production, soil erosion, land and forest degradation are intertwined with climate change in hilly regions. Human induced land degradation in the form of water erosion through unsustainable crop production is severe in the hills (Hossain, 2011). Besides, recently large-scale tobacco cultivation in the valley of the CHTs demands a huge amount of fuelwood for its curing, and imposing threat to the forest landscapes of hills (Bala et al., 2010). Crop productivity in jhum has declined due to soil erosion and associated reduction in essential soil nutrients (Karim and Mansor, 2011). On an average 40-45 $\mathrm{t} \mathrm{ha}^{-1} \mathrm{yr}^{-1}$ soil is eroded from due to shifting cultivation, the highest erosion was observed in steep slopes (33-42\%) and the lowest in gentle slopes (15\%) (Shoaib et al., 1998). Conservation of natural resources and sustainable crop production are twin development issues in the CHTs. Government, NGOs and some foreign agencies have been trying for about 20 years to promote alternative land uses in the CHTs for restoring natural resources and biodiversity, and improving the livelihoods of the hill dwellers (Kibria et al., 2015). In some areas of CHTs, alternative land uses such as agroforestry, multistoried fruit orchard, tree farming, and mixed horticulture are practiced as well as livestocks are integrated to farming system.

However, there is very limited and scattered information on crop agriculture in the CHTs. A study was therefore, undertaken to accumulate the information on crop agriculture of CHTs with an aim to elucidate the existing crop production systems and their performances, impacts of hill agriculture on environment, and the suitable cropping system for sustainable agricultural production in CHTs.

\section{CROP AGRICULTURE SYSTEM IN CHTS}

Agriculture is the main source of livelihood and the incidence of poverty is very high in CHTs (Ahammad and Stacey, 2016). About two thirds of rural households are farming households (Barkat et al., 2009) including 19\% jhum households, 34\% field cropping (plough cultivation) households, and 9\% field and jhum agriculture; rest 38\% households non-agricultural in CHTs (Ullah and Shamsuddoha, 2014). The two main land forms in the hilly areas are the hills and the valleys. The cultivation technologies practiced in CHTs for crop culture are plough and jhum, depending upon the suitability of the land. In CHTs, $35.87 \%$ land uses for forest, $27.60 \%$ for horticultural crops, $16.22 \%$ plough land, $15.52 \%$ Jhum land and rest $4.79 \%$ for settlements 
(Figure 1). Hill dwellers of CHTs mainly engage in fruit orcharding and shifting cultivation (jhum). Generally, valley dwellers engage in the plough cultivation of rice and tobacco, along with a few amounts of vegetable and fruit production (Nathan et al., 2013).

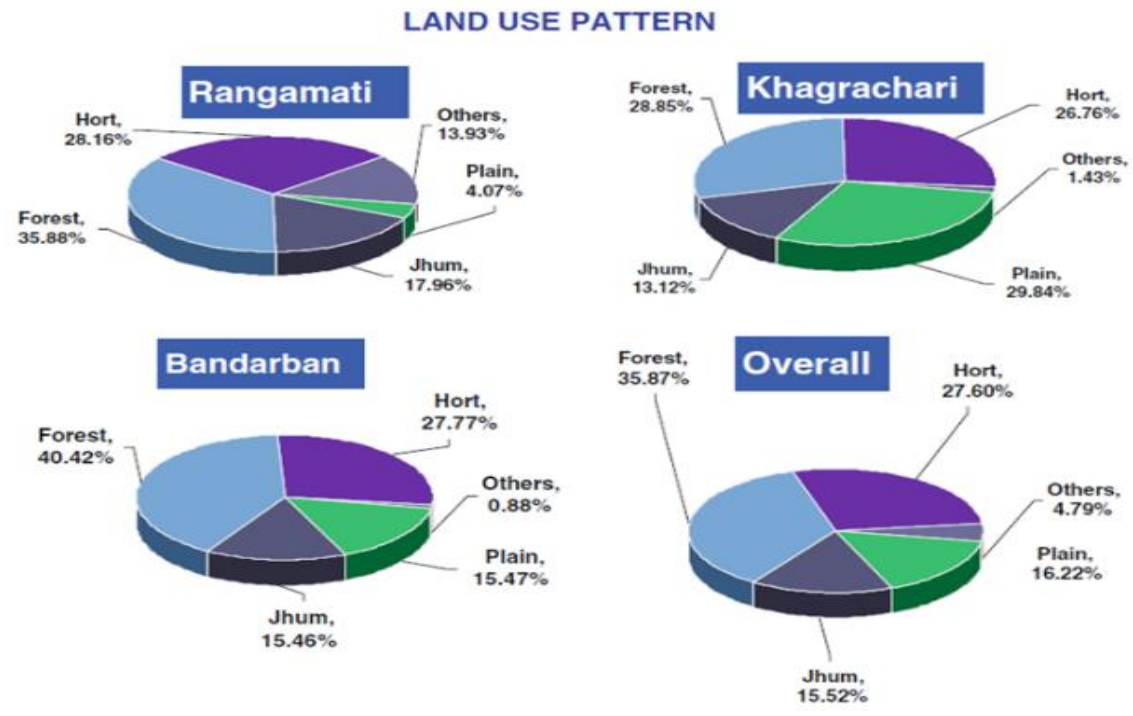

\section{Figure 1: Land use patterns of the Chittagong Hill Tracts (Bala et al., 2013).}

Distribution of agricultural income is varied by season in CTHs, total income is high in the wet season when households can collect grain crops, fruits and vegetables (Rahman et al., 2014). Agricultural income of the farmers of CHTs was higher during June to November (wet season) and lower during December to May (cool and dry season) (Rahman et al., 2014). During winter and dry seasons farmers of the area cannot grow any crop due to lack of water, only banana can be harvested at this time.

\subsection{Cropping Patterns in CHTs}

Annual crop based top cropping pattern in the CHTs was Boro-Fallow-T. Aman which accounts 15.07\% NCA of CHTs followed by Fallow-Fallow-T. Aman (13.68\% of NCA), FallowAus+Non-rice (shifting cultivation $9.24 \%$ of NCA) and others (Table 1).

Table 1: Major cropping patterns in CHTs

\begin{tabular}{lllll}
\hline SL. & Cropping pattern & Practicing site & Area (ha) & \% of NCA of CHTs \\
\hline 1 & Boro-Fallow-T. Aman & floodplains & 19400 & 15.07 \\
2 & Fallow-Fallow-T. Aman & valley & 17610 & 13.68 \\
3 & Fallow-Aus+Non-rice (Jhum) & hill slope & 11900 & 9.24 \\
4 & Vegetable-Fallow-Fallow & floodplains & 6310 & 4.90 \\
5 & Vegetable-Fallow-T. Aman & valley & 5450 & 4.23 \\
\hline
\end{tabular}


International Journal of Agriculture and Environmental Research

ISSN: 2455-6939

Volume: 06, Issue: 05 "September-October 2020"

\begin{tabular}{lllll}
\hline 6 & Boro-Fallow-Fallow & floodplains & 4950 & 3.85 \\
7 & Vegetable-Vegetable-Fallow & valley & 4890 & 3.80 \\
8 & Tobacco-Aus-Fallow & valley & 2250 & 1.75 \\
9 & Vegetable-Vegetable-T. Aman & valley & 1850 & 1.44 \\
10 & Tobacco-Fallow-T. Aman & valley & 1540 & 1.19 \\
11 & Fallow-Aus-T. Aman & valley & 1320 & 1.03 \\
\hline
\end{tabular}

NCA: Net Cropped Area.

Source: Quais et al., 2017.

\subsection{Plain land Plough Agriculture}

Plain land basically occupies valley bottoms, river bank and lower slopes in the CTH which are suitable for plough agriculture. Valleys and floodplains suitable for plough agriculture cover only 3.2\% (270812 ha) of the total land in CHTs. About $7 \%$ of the plough land produces three crops, $25 \%$ produces two crops, and $68 \%$ produces one crop per year (Olarieta et al., 2007). Rice, tobacco, sugarcane, potatoes, bilatidhonia, maize, cotton, groundnuts, beans, different vegetables and fruit species are cultivated with the plough technology in the plain lands. The rice productivity of plough land in the CHTs is much higher $\left(3.4 \mathrm{t} \mathrm{ha}^{-1}\right)$ than shifting cultivation $(1.5 \mathrm{t}$ $\left.\mathrm{ha}^{-1}\right)$; rice cultivation in the valleys of the CHTs can yields higher profit than cultivated on the plain land of the country (Nathan et al., 2013).

\subsubsection{Tobacco}

Tobacco is also one of the most important cash crops and largely grown as a monocrop by intensive farming in almost all areas of CHTs (Motaleb and Irfanullah, 2011). Tobacco cultivation started after 1990 with assistance from some local and multinational companies in this area. Presently, at least eight multinational companies are involved in tobacco cultivation and they motivate the farmers by offering incentives in cash. Most of the farmers in CHTs have been losing their interests in cultivating indigenous crops like paddy, banana, maize, sesame, cotton etc. and at least 7000 farmers are involved in tobacco cultivation (Ullah and Shamsuddoha, 2014). About 3918 ha of land produced 6326 MT tobacco in CHTs and Cox'Bazar districts during 2017-18, of which 2660 ha of land occupied cultivation only in Bandarban (BBS, 2019). Farmers cultivate tobacco during October-November and harvest during April-May of the following year.

\subsubsection{Spiny Coriander}

Spiny coriander (Eryngiumfoetidum) is a shade tolerant plant is commonly known as Bilatidhonia suited to climatic conditions of Chittagong Hill Tracts. Cultivation of Spiny coriander is increasing in CHTs as the net benefit of this farming is very high (4022680 Tk/ha). A Study in two village of CHTs found that the majority of farmers (86\%) preferred to cultivate 
spiny coriander (Hossain et al., 2017). It is an annual crop with a cropping cycle of 8-10 months and the cycle starts in January and continues until October (Figure 2). Field study on Spiny coriander reported that the average yield was $59.22 \mathrm{t} \mathrm{ha}^{-1}$ in CHTs and on average spiny coriander cultivation per household earned $472345 \mathrm{Tk}$. in every year (Table 2).

\begin{tabular}{|c|c|c|c|c|c|c|c|c|c|c|c|}
\hline \multirow[b]{2}{*}{ Activities } & \multicolumn{11}{|c|}{ Month } \\
\hline & Jan & Feb & Mar & Apr & May & Jun & Jul & Aug & Sep & Oct & \begin{tabular}{l|l} 
Nov & Dec
\end{tabular} \\
\hline \multicolumn{12}{|l|}{ Land preparation } \\
\hline \multicolumn{12}{|c|}{$\begin{array}{l}\text { Construction of shade } \\
\text { house }\end{array}$} \\
\hline \multicolumn{12}{|c|}{ Seed broadcasting } \\
\hline \multicolumn{12}{|l|}{ Weeding } \\
\hline \multicolumn{12}{|l|}{ Fertilization } \\
\hline \multicolumn{12}{|l|}{ Irrigation } \\
\hline Harvesting & & & & & & & & & & & \\
\hline
\end{tabular}

Figure 2: Spiny coriander production cycle in CHTs (Hossain et al., 2017).

\subsection{Slope Agriculture}

\subsubsection{Shifting Cultivation (Jhum) in CHTs}

Jhum cultivation is a special kind of subsistence farming on sloppy hills of the indigenous hilly people in CHTs. This method of cultivation is also known as "Slash and Burn" or "Swidden" cultivation. About 60000 families engaged in shifting cultivation in CHTs (Khan and Alam, 2015). The major steps of Jhum cultivation including land selection, land preparation, sowing and planting, weeding, pest management, harvesting, threshing and storing (Figure 3). Land preparation usually starts from March for jhum cultivation. At first, the standing vegetation are slashed and allowed to dry during the dry period. The dried vegetation and the fallen logs are burnt in the month of April and May. The partially burnt or unburned logs are then dragged out of the Jhum land and piled up. The land is ready for crop establishment at the first shower, which usually occurs in April or May. Sowing commences as soon as the monsoons starts and the ground is saturated, generally in the months of May and June. Seeds of different crops are sown combinedly in single hill as per the cultivator's provision. Harvesting starts from July and continued to December. 
International Journal of Agriculture and Environmental Research

ISSN: 2455-6939

Volume: 06, Issue: 05 "September-October 2020"

\begin{tabular}{|c|c|c|c|c|c|c|c|c|c|c|c|c|}
\hline Jhum farming activities & Jan & Feb & Mar & Apr & May & Jun & Jul & Aug & Sep & Oct & Nov & Dec \\
\hline \multicolumn{13}{|l|}{ Land selection } \\
\hline \multicolumn{13}{|l|}{ Land clear/ Preparation } \\
\hline \multicolumn{13}{|l|}{ Sowing and planting } \\
\hline \multicolumn{13}{|l|}{ Weeding } \\
\hline \multicolumn{13}{|l|}{ Pest and management } \\
\hline \multicolumn{13}{|l|}{ Vegetables harvesting } \\
\hline \multicolumn{13}{|l|}{ Melon harvesting } \\
\hline \multicolumn{13}{|l|}{ Cucumber and gourd harvesting } \\
\hline \multicolumn{13}{|l|}{ Rice and Maize harvesting } \\
\hline \multicolumn{13}{|l|}{ Chilli harvesting } \\
\hline \multicolumn{13}{|l|}{ Pumkin, Cheena harvesting } \\
\hline \multicolumn{13}{|l|}{ Brinjal harvesting } \\
\hline \multicolumn{13}{|l|}{ Cassava harvesting } \\
\hline \multicolumn{13}{|l|}{ Turmeric, ginger, arum, cotton harvesting } \\
\hline Drying & & & & & & & & & & & & \\
\hline
\end{tabular}

Figure 3: Jhum cropping calendar in CHTs(Chakma and Ando, 2008).

\subsubsection{Jhum Cycle Practices Field Size of Shifting Cultivation}

Jhum cycle means the fallow period of shifting cultivation. Jhum cycle period is reduced over times and in present situation practiced fallow period 2-3 years only for shifting cultivation. In the past (before 2000) farmers followed a cycle of more than 5 years (Table 3 ). The jhum cycle period is reduced due to establishment of hydroelectric dam, settlement of plain land people in hills, demographic pressure, declaring of forest protected areas, and increasing new plantation area. Before creation of Kaptai Dam the jhum cycle was 10 to 20 years or even more (Chakma and Ando, 2008).

Table 3: Trend of reduction of Jhum cycle period for shifting cultivation

\begin{tabular}{lll}
\hline Period & Fallow period & Causes for reduction of fallow period \\
\hline $1990-2000$ & 5-10 years & $\begin{array}{l}\text { Because of construction of hydroelectric dam, many lowland people } \\
\text { moved to high hill }\end{array}$ \\
$2000-2005$ & 4-5 years & $\begin{array}{l}\text { Because of huge settlement of plain land people } \\
\text { Because of increasing population and declaring of protected areas }\end{array}$ \\
$2005-2010$ & 3-4 years & Because of increasing population and plantation forest
\end{tabular}

Source: Karim and Mansor, 2011; Chakma and Nahar, 2012; Hossain and Ahmed, 2017.

A study on jhum cultivation in Bandarban hill district found that $48 \%$ jumia (Jhum farmers) cultivated 101-200 decimal, 27\% cultivated 0-100 decimal, 19\% cultivated 201-400 decimal, and only $6 \%$ cultivated more than 400 decimals of jhum land (Hossain and Ahmed, 2017). In Rangamati, most of the jumia (60\%) have only 1-2 acres of land for jhum cultivation and $25 \%$ of the Jumia have 2.1-3 acres of land (Chakma and Nahar, 2012). 


\subsubsection{Crops and yield potentials of Shifting Cultivation}

Jhum farmers cultivate crops whatever they need including cereals, vegetable, pulse, oilseed, spices, fruits and fiber. Previously, 15-20 crops used to be grown together, now 5-8 crops were usually grown in a Jhum field (Chakma and Ando, 2008). Generally, flat to moderate-sloping land is used for annual crops such as upland rice, ginger, turmeric, chilli, cassava, cucurbits, pigeon pea, sorghum, maize; steep-sloping land for growing different annual crops but with the maintenance of vegetative covers such as contour bio-hedgerows of leguminous plants and trees to protect top soil; and very steep land is used for growing jackfruit, guava and lemon while the north, east and north east slopes were used for planting local varieties of banana and plantain (Musa paradisiaca) (Table 4). Rice is the major crop component of jhum field and average yield $1.15 \mathrm{t} \mathrm{ha}^{-1}$, though rice grown as main crop banana provides the maximum yield of $108 \mathrm{t} \mathrm{ha}^{-1}$ (Jamaluddin et al., 2010). Yields of different crops in jhum plots greatly varied due to rainfall variability, number of crops sown and management practices. However, in recent times few Jhum cultivators is more interested to produce cash crops like ginger and turmeric rather than paddy.

Table 4: Basic sloping-land farming practices in jhum plots of CHTs

\begin{tabular}{|c|c|c|c|c|c|c|}
\hline \multirow{2}{*}{$\begin{array}{l}\text { Slope } \\
\text { Category }\end{array}$} & \multicolumn{6}{|c|}{ Crop type } \\
\hline & $\begin{array}{l}\text { Annual } \\
\text { cereal/tuber }\end{array}$ & $\begin{array}{l}\text { Annual } \\
\text { vegetable }\end{array}$ & $\begin{array}{l}\text { Annual } \\
\text { pulse }\end{array}$ & $\begin{array}{l}\text { Annual spice/ } \\
\text { herb/oilseed/other }\end{array}$ & $\begin{array}{l}\text { Annual } \\
\text { fruit }\end{array}$ & Perennial fruit \\
\hline $\begin{array}{l}\text { Moderate } \\
\text { slope } \\
(0-35 \text { degree })\end{array}$ & $\begin{array}{l}\text { Rice, } \\
\text { Sorghum, } \\
\text { Millet, } \\
\text { Maize, } \\
\text { Cassava }\end{array}$ & Cucurbits & $\begin{array}{l}\text { Pigeon } \\
\text { pea }\end{array}$ & $\begin{array}{l}\text { Ginger, } \\
\text { Chilli, } \\
\text { Sesameric, } \\
\text { Cotton }\end{array}$ & Melons & $\begin{array}{l}\text { Mango, Wood } \\
\text { apple }\end{array}$ \\
\hline $\begin{array}{l}\text { Steep slope } \\
(36-65 \\
\text { degree })\end{array}$ & $\begin{array}{l}\text { Rice, } \\
\text { Sorghum, } \\
\text { Maize, } \\
\text { Cassava }\end{array}$ & Cucurbits & $\begin{array}{l}\text { Pigeon } \\
\text { pea }\end{array}$ & $\begin{array}{l}\text { Ginger, Turmeric, } \\
\text { Chilli, Cotton }\end{array}$ & & $\begin{array}{l}\text { Leguminous } \\
\text { tree species, } \\
\text { Aonla }\end{array}$ \\
\hline $\begin{array}{l}\text { Very steep } \\
\text { slope } \\
(>65 \text { degree) }\end{array}$ & - & - & - & - & $\begin{array}{l}\text { Banana, } \\
\text { Plantain }\end{array}$ & $\begin{array}{l}\text { Jackfruit, } \\
\text { Guava, Lemon }\end{array}$ \\
\hline
\end{tabular}

Source: Misbahuzzaman, 2016.

\subsubsection{Improved Jhum Cultivation}

Generally, farmers use local cultivars without any fertilizer and rarely manage diseases and insect's pest in jhum cultivation. Only 50-60\% farmers use synthetic fertilizer and Pesticides, and $8 \%$ of the farmers applied in jhum fields (Olarieta et al., 2007). In improved method of jhum 
farming farmer uses high yielding varieties, chemical fertilizers and pest management for obtaining higher yield. Field study on improved jhum produced the higher yields of different crops than traditional local jhum (Table 5). About 40\% higher Rice Equivalent Yield (REY) was recorded in improved jhum $\left(6786.8 \mathrm{kgha}^{-1}\right)$ than local jhum $\left(4339.8 \mathrm{kgha}^{-1}\right)$. Rate of return of improved jhum was higher (2.15) than traditional jhum (1.56).

Table 5: Yields of different component crops and total REY of improved and traditional jhum practice

\begin{tabular}{|c|c|c|c|c|c|c|c|c|c|}
\hline $\begin{array}{l}\text { Jhum } \\
\text { System }\end{array}$ & $\begin{array}{l}\text { Rice } \\
\text { grain } \\
\text { yield } \\
(\mathrm{kg} / \mathrm{ha})\end{array}$ & $\begin{array}{l}\text { Seed } \\
\text { cotton } \\
\text { yield } \\
(\mathrm{kg} / \mathrm{ha})\end{array}$ & $\begin{array}{l}\text { Sesame } \\
\text { seed } \\
\text { yield } \\
(\mathrm{kg} / \mathrm{ha})\end{array}$ & $\begin{array}{l}\text { Maize } \\
\text { green } \\
\text { cob } \\
\text { yield } \\
(\mathrm{kg} / \mathrm{ha})\end{array}$ & $\begin{array}{l}\text { Chilli } \\
\text { fruit } \\
\text { yield } \\
(\mathrm{kg} / \mathrm{ha})\end{array}$ & $\begin{array}{l}\text { Marfa } \\
\text { fruit } \\
\text { yield } \\
(\mathrm{kg} / \mathrm{ha})\end{array}$ & $\begin{array}{l}\text { Total Rice } \\
\text { Equivalent } \\
\text { Yield } \\
(\mathrm{REY}) \\
(\mathrm{kg} / \mathrm{ha})\end{array}$ & $\begin{array}{l}\% \text { Increase } \\
\text { of REY } \\
\text { over } \\
\text { traditional } \\
\text { jhum }\end{array}$ & $\begin{array}{l}\text { Benefit } \\
\text { Cost Ratio }\end{array}$ \\
\hline Improved & 3113 & 456 & 478 & 627 & - & - & 6786.8 & $40.23 \%$ & 2.15 \\
\hline Traditional & 2007 & 287 & 206 & 393 & 146 & 600 & 4339.8 & - & 1.56 \\
\hline LSD (0.05) & 120.89 & 99.52 & 44.5 & 32.74 & - & - & - & - & - \\
\hline CV\% & 19.25 & 17.67 & 12.73 & 10.34 & - & - & - & - & - \\
\hline
\end{tabular}

Source: Mahmud et al., 2018.

\subsubsection{Advantages and Disadvantages of Shifting Cultivation}

Despite having some advantages of jhum cultivation there are many disadvantages. Traditional and easy method of cultivation with low investment, locally available planting materials and short rotation are the key benefits of jhum farming (Aktar et al., 2019; Nath et al., 2016b). In contrast soil erosion, biodiversity loss, deforestation, land degradation, very high dependency on nature, lower yield, fertilizer and pesticides requirement, little profit margin, negative response from government authority etc. are disadvantages of jhum farming (Nath et al., 2016a; Aktar et al., 2019).

\subsection{Monocropping System of High value crops}

The CHTs has a favourable agro-climatic environment for cultivating a number of high-value crops. This region is suitable for growing high value crops like turmeric, ginger, pineapple, aroids, papaya, banana (Rasul and Tripura, 2016). Cultivation of turmeric and ginger on hill slope has become a potential factor for the tribe to earn cash income which has brought a positive change on their livelihood in the CHTs; and hilly farmers have been gaining economic stability through cultivating turmeric and ginger (The Dhaka Tribune, 2014). Almost all the traditional farmers grow turmeric as it is more profitable than any other crops like paddy and banana (Chakma, 2008). In CHTs, about 8000 ha of land are being used to cultivate turmeric and ginger, and together produces almost 50000 Metric ton of fresh rhizome in every year (Figure 4). 
Being an exhaustive crop and intensive monocropping practice the production of turmeric are reducing in recent years (Figure 4).There are also increasing levels of pineapple cultivation as vital source of cash flow, particularly in the last two decades (Ahammad and Stacey, 2016). In recent years, more than 2700 ha land are used for growing pineapple and 40000 metric ton fruits are produced every year (Table 6).

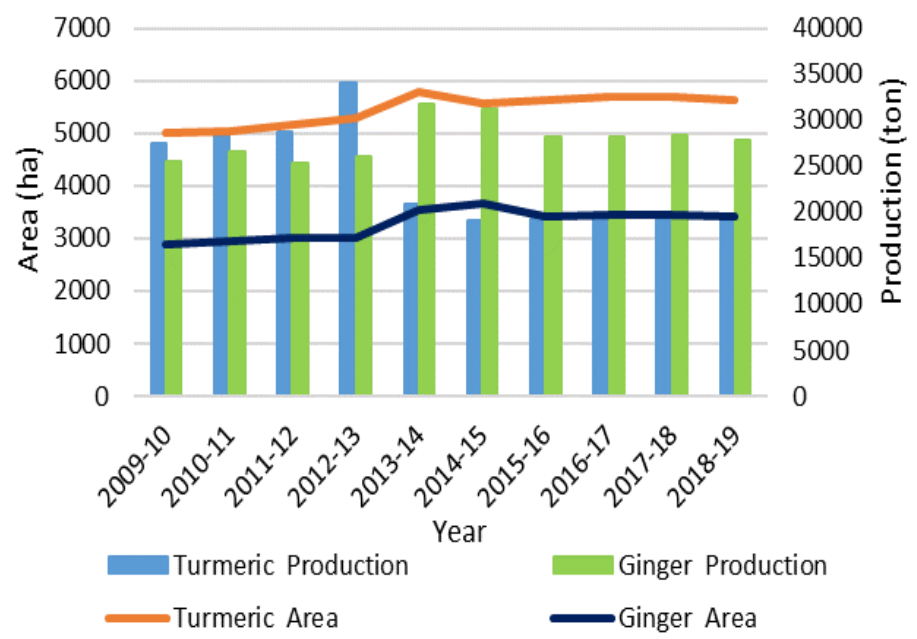

Figure 4: Trend of turmeric and ginger growing area and production in CHTs (BBS, 2020; BBS, 2017; BBS, 2014; BBS, 2012)

Table 6: Area and production of pineapple in CHTs

\begin{tabular}{ccccccccc}
\hline \multirow{2}{*}{ Year } & \multicolumn{4}{c}{ Area (ha) } \\
\cline { 2 - 9 } & Bandarban & Khagrachari & Rangamati & $\begin{array}{c}\text { Total } \\
\text { CHTs }\end{array}$ & Bandarban & Khagrachari & Rangamati & $\begin{array}{c}\text { Total } \\
\text { CHTs }\end{array}$ \\
\hline $2009-10$ & 604 & 686 & 1278 & 2568 & 7074 & 6399 & 22209 & 35682 \\
$2010-11$ & 610 & 707 & 1278 & 2595 & 7336 & 7942 & 22056 & 37334 \\
$2011-12$ & 574 & 737 & 1281 & 2592 & 6778 & 7497 & 24670 & 38945 \\
$2012-13$ & 579 & 736 & 1283 & 2598 & 6839 & 7494 & 25000 & 39333 \\
$2013-14$ & 387 & 734 & 1274 & 2395 & 3891 & 7624 & 24070 & 35585 \\
$2014-15$ & 601 & 811 & 1319 & 2731 & 6399 & 10682 & 25173 & 42254 \\
$2015-16$ & 607 & 828 & 1328 & 2763 & 6256 & 10142 & 24661 & 41059 \\
$2016-17$ & 610 & 800 & 1343 & 2753 & 6316 & 6645 & 25027 & 37988 \\
$2017-18$ & 618 & 810 & 1338 & 2766 & 6204 & 7290 & 25044 & 38538 \\
$2018-19$ & 619 & 832 & 1347 & 2798 & 6215 & 7596 & 25235 & 39046 \\
\hline
\end{tabular}




\subsection{Modern Land use in CHTs}

There are many alternate modern farming systems in the CHTs including Multi-storey Fruit Garden (MSFG), Multi-strata Agroforestry System (MAFS), Sloping Agricultural Land Technology (SALT), Modern Agricultural Technology (MATH), and Contour Hedgerow Intercropping Agro-forestry Technology (CHIAT). Both Bengali and ethnic indigenous farmers are now very interested in fruit production and agroforestry practices. Since 1860 efforts were made to control shifting cultivation and promote alternative farming systems in CHTs (Rasul et al., 2004). Over last couple of decades, alternative land uses with perennial horticultural species with or without timber trees have increased in CHTs.

A pair-wise comparison of three factors of sustainability (social, economic and environmental) study to evaluate farmer's preference for land uses in CHTs revealed that participants emphasized most on the economic (75\%) aspect over social (17\%) and environmental (8\%) aspects (Table 7). In respect to social and economic aspects, the priority vector was the highest (0.628 and 0.618$)$ in orchards. The environmental priority vector was the highest $(0.44)$ for agroforestry. By considering overall priority, it was observed that orchards were the most preferred land use with a composite weight of all priority vectors $(0.60$ or $60 \%$ preference $)$ followed by agroforestry (0.25) among the four land uses (Table 7). Bala et al., (2013) reported that at least 30\% of total land uses cover different types of fruit plantation in the CHTs. Fruits production is increasing day by day in CHTs. Many commercial fruit gardens of mango, sweet orange, litchi, pineapple, dragon fruit etc. has been established in this area.

Table 7: Land use priority in CHTs by considering the sustainability factors

\begin{tabular}{lccccc}
\hline Land use category & $\begin{array}{c}\text { Contribution to } \\
\text { Household income (\%) }\end{array}$ & $\begin{array}{c}\text { Social } \\
(0.17)\end{array}$ & $\begin{array}{c}\text { Economic } \\
(0.75)\end{array}$ & $\begin{array}{c}\text { Composite } \\
\text { weight }\end{array}$ \\
& & 0.628 & 0.618 & 0.308 & 0.595 \\
\hline Fruit orchard & 62 & 0.174 & 0.246 & 0.447 & 0.250 \\
Agroforestry & 55 & 0.046 & 0.090 & 0.066 & 0.080 \\
Shifting cultivation & 48 & 0.152 & 0.046 & 0.179 & 0.075 \\
Village common & 35 & & & & \\
forest (VCF) & & & & & \\
\hline
\end{tabular}

Source: Kibriaet al., 2015.

\subsubsection{Multi-storey Fruit Garden (MSFG)}

Multi-storey fruit gardening is getting popularity in the CHTs. Different fruit species have gradually replaced shifting cultivation due to increasing demand for cash incomes (Ahammad and Stacey, 2016). A good number of fruit species are produced in different vertical strata of the orchards. A holistic comparison of performances of MSFG with sole cropping is shown in Table 
8. The economic analysis revealed that the maximum gross margin was calculated from MSFG (TK. 12, 47,085) followed by sweet orange (TK 9, 04,687) and the lowest from litchi (TK. 88,836) (Table 9). The highest BCR 6.79 was also recorded in MSFG followed by sweet orange orchard (5.47) and coconut orchard (3.46). The LER (2.6) of MSFG was much higher than sole orchards. Higher production and benefits from MSFG might be due to maximum complementary use of different growth resources. MSFG system has been found suitable for preventing soil erosion and forest degradation, and in boosting the cropping intensity in hilly areas (Paul and Hossain, 2001).

\section{Table 8: Performance of different fruits in multi-storey fruit garden and sole cropping system in CHTs}

\begin{tabular}{ccccccccc}
\hline Systems & \multicolumn{2}{c}{ Coconut } & \multicolumn{2}{c}{ Litchi } & \multicolumn{2}{c}{ Malta } & \multicolumn{2}{c}{ Pineapple } \\
\cline { 2 - 9 } & $\begin{array}{c}\text { Single nut } \\
\text { weight } \\
(\mathrm{kg})\end{array}$ & $\begin{array}{c}\text { Yield per } \\
\text { plant }\end{array}$ & $\begin{array}{c}\text { Fruits per } \\
\text { plant }\end{array}$ & $\begin{array}{c}\text { Yield per } \\
\text { plant } \\
(\mathrm{kg})\end{array}$ & $\begin{array}{c}\text { Fruits per } \\
\text { plant }\end{array}$ & $\begin{array}{c}\text { Yield per } \\
\text { plant } \\
(\mathrm{kg})\end{array}$ & $\begin{array}{c}\text { Single } \\
\text { fruit } \\
\text { wt. }(\mathrm{g})\end{array}$ & $\begin{array}{c}\text { Fruit } \\
\text { yield } \\
\left(\mathrm{t} \mathrm{ha}{ }^{-1)}\right.\end{array}$ \\
\cline { 2 - 9 } MSFG & 1.25 & 81.09 & 599.55 & 9.90 & 106.15 & 24.78 & 560.0 & 31.25 \\
Sole & 1.45 & 119.27 & 658.62 & 11.94 & 113.0 & 24.87 & 530.0 & 29.50 \\
$\mathrm{t}$ test & $* *$ & $* *$ & $* *$ & $*$ & $\mathrm{~ns}$ & $\mathrm{~ns}$ & $* *$ & $* *$ \\
$\begin{array}{l}\text { ns = non-significant, } \\
\text { probability. }\end{array}$
\end{tabular}

Source: Rahman et al., 2014.

Table 9: Cost-return analyses of different fruit crops as sole and their combination in multi-storey fruit garden

\begin{tabular}{lccccc}
\hline Systems & $\begin{array}{c}\text { Gross return } \\
\left(\text { Tk. ha }{ }^{-1} \text { yr. }^{1}\right)\end{array}$ & $\begin{array}{c}\text { Total variable cost } \\
\left(\text { Tk. ha }{ }^{-1} \mathrm{yr}^{1}\right)\end{array}$ & $\begin{array}{c}\text { Gross margin } \\
\left(\text { Tk. ha }{ }^{-1} \text { yr. }{ }^{1}\right)\end{array}$ & $\begin{array}{c}\text { Benefit-Cost } \\
\text { Ratio (BCR) })\end{array}$ & $\begin{array}{c}\text { Land Equivalent } \\
\text { Ratio (LER) }\end{array}$ \\
\hline $\begin{array}{l}\text { Multi-storey Fruit } \\
\text { Garden (MSFG) }\end{array}$ & $14,62,534$ & $2,15,451$ & $12,47,083$ & 6.79 & 2.6 \\
Coconut (sole) & $4,00,000$ & $1,15,520$ & $2,84,479$ & 3.46 & 1.0 \\
Litchi (sole) & $2,08,593$ & $1,19,756$ & 88,836 & 1.74 & 1.0 \\
Sweet orange (sole) & $11,06,875$ & $2,02,187$ & $9,04,687$ & 5.47 & 1.0 \\
Pineapple (sole) & $3,64,583$ & $2,07,673$ & $1,56,909$ & 1.76 & 1.0 \\
\hline & & & Source: Rahman et al., 2014.
\end{tabular}

\subsubsection{Agroforestry System (AFs)}

Jhum land has been gradually replaced by agroforestry and tree-based land uses in CHTs. Farmers moved toward market-oriented horticultural crop-based agroforestry system for cash income generation. In CHTs, different crops, fruits and timber species are grown under different 
Volume: 06, Issue: 05 "September-October 2020"

slope of agroforestry systems (Table 10). Uses and planting of medicinal plants in CHTs are the old-age practices over there.

Table 10: Agroforestry based farming practices in different slopes of CHTs

\begin{tabular}{|c|c|c|c|}
\hline \multirow{2}{*}{$\begin{array}{l}\text { Slope category } \\
(\%)\end{array}$} & \multicolumn{3}{|c|}{ Component types } \\
\hline & Crop species & Fruit species & Forest species \\
\hline $\begin{array}{l}\text { Up to } 5 \% \\
\text { (Level to gentle sloping) }\end{array}$ & $\begin{array}{c}\text { Upland rice, Vegetable, } \\
\text { Ginger, Turmeric }\end{array}$ & $\begin{array}{c}\text { Banana, Pineapple, Lemon, } \\
\text { Guava, Papaya, Custard apple, } \\
\text { Areca nut }\end{array}$ & - \\
\hline $\begin{array}{l}5-15 \% \\
\text { (Sloping) }\end{array}$ & $\begin{array}{l}\text { Upland rice, Legume, } \\
\text { Vegetable, Ginger, } \\
\text { Turmeric }\end{array}$ & $\begin{array}{c}\text { Banana, Pineapple, Lemon, } \\
\text { Guava, Papaya, Custard apple, } \\
\text { Areca nut }\end{array}$ & - \\
\hline $\begin{array}{l}15-30 \% \\
\text { (Moderate steep) }\end{array}$ & Upland rice & $\begin{array}{c}\text { Banana, Pineapple, Litchi, } \\
\text { Jackfruit, Mango, Amra, Wood } \\
\text { apple, Areca nut }\end{array}$ & - \\
\hline $\begin{array}{l}30-60 \% \\
\text { (Steep) }\end{array}$ & Upland rice & Banana & $\begin{array}{l}\text { Bamboo, Teak, } \\
\text { Gamar, Koroi, }\end{array}$ \\
\hline $\begin{array}{l}\text { Above } 60 \% \\
\text { (Very steep) }\end{array}$ & Upland rice & Banana & $\begin{array}{c}\text { Cassia, Acacia } \\
\text { Leucaena }\end{array}$ \\
\hline
\end{tabular}

\subsubsection{Multi-strata Agroforestry System (MAFS)}

Mostly multi-storey agroforestry systems in CHTs consists of vegetables, spices and fruits. The under storey comprises of various annual crops, the middle of shrubs like banana, papaya, lime, guava and the upper storey with timber and fruit species (Table 11). Farmers grow up to 15 species of seasonal crops together in their agroforestry fields for their own consumption and for sale. Benefit-cost analysis showed a significant increasing net-benefit as the number of crop species used in agroforestry system increased, while a reverse trend was showed for production cost (Figure 5a). In studied multistorey agroforestry system, under-storied crops provided $77 \%$ net-benefits and the overall BCR of the system was 3.03 (Table 11). 
International Journal of Agriculture and Environmental Research

ISSN: 2455-6939

Volume: 06, Issue: 05 "September-October 2020"

Table 11: Benefit-cost analysis of multi-storey agroforestry plots in CHTs

\begin{tabular}{llcccc}
\hline Strata & Component crops & $\begin{array}{c}\text { Costs } \\
(\mathrm{BDT})(\%)\end{array}$ & $\begin{array}{c}\text { Benefits } \\
(\mathrm{BDT})(\%)\end{array}$ & $\begin{array}{c}\text { Net-Benefits } \\
(\mathrm{BDT})(\%)\end{array}$ & BCR \\
\hline Under & Vegetables, Tuber crops, & 22,661 & 66,379 & 43,718 & 2.93 \\
storey & Pineapple & $(81)$ & $(78)$ & $(77)$ & \\
Middle & Cassava, Banana, Lemon, Papaya, & 3231 & 12,900 & 9669 & 3.99 \\
storey & Guava, Malta & $(11)$ & $(15)$ & $(17)$ & \\
Upper & Wood apple, Litchi, Mango, & 2118 & 5480 & 3362 & 2.59 \\
storey & Orange, Drum stick, Teak, Acacia & $(8)$ & $(7)$ & $(6)$ & \\
Total & & $28010(100)$ & $84759(100)$ & $56749(100)$ & 3.03 \\
\hline
\end{tabular}

\subsubsection{Sloping Agricultural Land Technology (SALT)}

Bangladesh Forest Research Institute (BFRI) has developed Sloping agricultural land technology (SALT) in the hills for sustainable land management. In SALT, annual crops are grown between hedgerows in bands measuring 40-50 $\mathrm{m}$ wide. There are four popular model of SALT including Sloping Agricultural Land Technology (SALT-1), Sloping Agroforest Land Technology (SALT2), Sloping Agro-livestock Land Technology (SALT-3) and Sloping Agro-fisheries Livelihood Technology (SALT-4) are effectively practiced in CHTs (Khan and Alam, 2015). The SALT increases soil fertility status, decreases erosion and slows the flow of rainfall down the slope.

\subsection{Impacts of Hill Agriculture on Environment}

Shifting cultivation and plough agriculture on slopping area accelerates land degradation, forest degradation, and biodiversity destruction in hilly region through deforestation and burning. As a result, the whole environment is disrupted. Among all practices, plough cultivation and tobacco cultivation are posing a great threat to the agriculture, forests, and environment in hilly areas. Indiscriminate tobacco cultivation leaves a negative impact on soil fertility and once tobacco is cultivated it is difficult to grow other crops on the same land, it's a great threat for agrobiodiversity, as this limits farmers' freedom of choice for crop production (Akhter et al., 2014; Islam et al., 2010). At least 60000-70000 MT of fuelwood are being burnt in 2000 tobacco processing kilns every year, causing depletion of natural forests, threatening environment and biodiversity in the hills (Ullah and Shamsuddoha, 2014). About 13-14 tons of fuelwood is needed to process tobacco leaves grown on one hectare of land. Indigenous farming methods for growing different annual crops in hill slope and improper management of soil enhanced soil erosion and created negative impact on soil productivity. Chakma and Nahar (2012) reported the negative impacts of jhum cultivation on environment which are listed below: 
Volume: 06, Issue: 05 "September-October 2020"

- Loss of forest area (Deforestation)

- Loss of top soil

- Increase landslide

- Loss of animal biodiversity

- Loss of plant biodiversity
- Decrease environmental balance

- Source of forest fire

- Increase temperature

- Decrease biomass and soil carbon storage

- Decrease soil productivity

Extensive farming activities like heavy spading, crop cultivation along with slope, earthing up, slush, and burning caused soil erosion from the hill slope.Mono-cropping of turmeric, ginger, pineapple, aroids, rubber plants, and other crops, has increased runoff soil erosion and loss of essential nutrients and biodiversity (Khisa and Mohiuddin, 2015).Losses of top soil from hill causes organic matter depletion and resulting nutrient exhaustion in soil. Thus, hill cultivation degrades land productivity and causes excess runoff. The CHTs receives $250-375 \mathrm{~cm}$ rain annually. High intensity rainfall and heavy shower accelerates the rate of soil erosion at the beginning of the monsoon when the sloping land has been cleared for Jhum and remains bare or sporadically covered with newly emerging seedlings. In CHTs, the maximum soil loss was recorded in annual crops cultivation without mulching $\left(99.15 \mathrm{t} \mathrm{ha}^{-1} \mathrm{yr}^{-1}\right)$ followed by shifting cultivation $\left(41.23 \mathrm{t} \mathrm{ha}^{-1} \mathrm{yr}^{-1}\right)$ where least $\left(10 \mathrm{t} \mathrm{ha}^{-1} \mathrm{yr}^{-1}\right)$ soil loss occurs for agroforestry and orcharding (Table 12). The factors influencing soil loss are rainfall, land slope, slope length, land management practices, vegetation cover density etc.

Table 12: Soil erosion under different agricultural land use system in CHTs

\begin{tabular}{|c|c|c|c|c|}
\hline Land use & & $\begin{array}{c}\text { Average soil } \\
\text { Loss } \\
\left(\mathrm{t} \mathrm{ha}^{-1} \mathrm{yr}^{-1}\right)\end{array}$ & $\begin{array}{l}\text { Natural rate of soil } \\
\text { formation } \\
\left(\mathrm{t} \mathrm{ha}^{-1} \mathrm{yr}^{-1}\right)\end{array}$ & $\begin{array}{l}\text { Net soil loss } \\
\left(\mathrm{t} \mathrm{ha}^{-1} \mathrm{yr}^{-1}\right)\end{array}$ \\
\hline \multirow{2}{*}{$\begin{array}{l}\text { Annual crops: mainly } \\
\text { root crops such as } \\
\text { Ginger, Turmeric, } \\
\text { Mukhikachu }\end{array}$} & $\begin{array}{l}\text { Conventional tillage: } \\
\text { hoeing without mulch }\end{array}$ & 99.15 & 15 & -84.15 \\
\hline & $\begin{array}{l}\text { Conventional tillage: } \\
\text { hoeing with mulch }\end{array}$ & 35.16 & 15 & -20.16 \\
\hline Pineapple & & 18.05 & 15 & -3.05 \\
\hline Shifting Cultivation & & 41.23 & 15 & -26.23 \\
\hline $\begin{array}{l}\text { Agroforestry, tree } \\
\text { farming, mixed } \\
\text { plantation }\end{array}$ & & 10 & 15 & +5 \\
\hline
\end{tabular}

\subsection{Sustainable Farming Model for Hilly Areas}

In the background of land and forest degradation along with demographic pressure three treebased sustainable farming models i.e. multistorey agroforestry system (MAFS), Multi-strata fruit 
orchards (MSFO) and complex fruit and timber-based mixedagroforest (SALT) are identified and suggested for hilly areas to maintain agricultural production and environmental gradient. Multistorey agroforestry system for the agricultural and shifting cultivation fields close or adjacent to the depleted natural forest areas (Figure 5a). This system is already practiced by few farmers in CHTs, and is well suited for regeneration of forest vegetation in the jhum fields close to villages. The system is based on fruits and timber trees in upper storey, shrubby and medium sized fruit species in middle storey together with vegetables, medicinal plants and tuber species in lower storey. Multi strata fruit orchards (MSFO) by arranging pineapple and papaya in lower strata, lemon, orange and guava in middle strata, mango and litchi in upper strata, and coconut and betel nut in top strata.

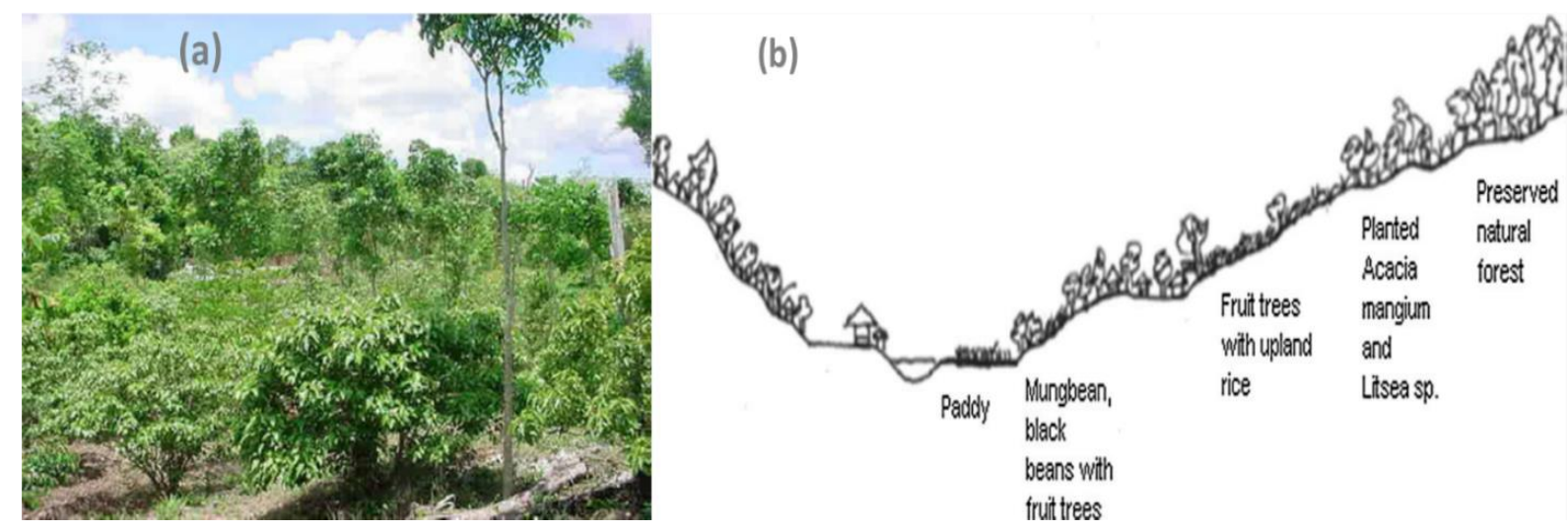

Figure 5: Recommended sustainable tree-based land use system for hilly areas (Rahman et al., 2014).

The other is the complex fruit and timber-based mixed conservation agroforest which can be established in the large depleted landscapes (Figure 5b). Timber species with bamboo could preserve hilltops by forming a mini forest with hydrological functions. Fruit trees can be planted next to the natural forest. For the purpose of food security, upland rice and maize can be intercropped with acacia, teak and fruit trees for the first 6 years. Subsequently, shade tolerant pineapple can be planted under fruit trees which can produce fruit after one year. Papaya, banana, lemon, guava, orange etc. can be planted next to fruit tree plantation. Mung bean and black beans can be intercropped with these at the foot of the hilly slope.

\section{CONCLUSION}

Overall, the study indicates that farming practices in the CHTs have undergone significant changes with the incorporation of new techniques and varieties into existing practices. In Chittagong Hill Tracts (CHTs) region of Bangladesh agriculture is the prime sources of livelihood. Rice, Maize, vegetables, spices, and tobacco are the major crops in valley of hilly 
International Journal of Agriculture and Environmental Research

ISSN: 2455-6939

Volume: 06, Issue: 05 "September-October 2020"

areas. In sloppy land shifting cultivation is the main cropping system, of which upland rice is the major crop components. Agroforestry, annual horticultural crops, and fruit orcharding are secondary land use system in CHTs. In terms of economic and environmental suitability agroforestry and fruit gardening were found to be sustainable. Natural resources specially land and forests are degrading gradually due to unsustainable agricultural land use practices in hilly areas including very short rotation shifting cultivation, tuber crops cultivation without mulching, tobacco cultivation etc. Extensive jhum practice influences the risk of forest fire during dry season and land slide during monsoon. Sustainable crop production to secure food stocks and reduce forest degradation is a challenge in hilly region. Tobacco cultivation in valley and floodplain should be replaced by high value annual crops. Tree based land use through agroforestry and fruit farming in CHTs are the viable strategy to protect natural forest and poverty reduction. Farmers can achieve direct benefits from agroforestry and orchards, in the form of food, fuelwood and cash income, and receive significant indirect environmental benefits.

\section{REFERENCES}

Ahammad, R., and Stacey, N. (2016). Forest and agrarian change in the Chittagong Hill Tracts region of Bangladesh. Agrarian change in tropical landscapes, p.190-233.

Aktar, L. A., Jubair, S. M. R., Jewel, K. N. E. Alam., and Akhter, S. (2019).Cultivation of medicinal plants through agroforestry. International journal of business, social and scientific research. 7(2): 08-13.

Bala, B. K., Majumder, S., Hossain, S. A., Haque, M. A., and Hossain, M. A. (2013). Exploring development strategies of agricultural systems of Hill Tracts of Chittagong in Bangladesh. Environment, development and sustainability, 15(4), 949-966.

Bala, B. K., Hossain, S. M. A., Haque, M. A., Majumder, S., and Hossain, M. A. (2010). Management of agricultural systems of the uplands of Chittagong hill tracts for sustainable food security, final technical report (PR-1), Dhaka.

Barkat, A., Halim, S., Poddar, A., Badiuzzaman, M., Osman, A., Khan, M. S., Rahman, M., Majid, M., Mahiyuddin, G., Chakma, S., and Bashir, S. (2009). Socio-economic baseline survey of Chittagong Hill Tracts. Human Development Research Centre (HDRC)/Chittagong Hill Tracts Development Facility (CHTDF)/UNDP, Dhaka.

BBS, (2020). Yearbook of Agricultural Statistics-2019. Bangladesh Bureau of Statistics, Ministry of Planning Government of the People's Republic of Bangladesh. 
International Journal of Agriculture and Environmental Research

ISSN: 2455-6939

Volume: 06, Issue: 05 "September-October 2020"

BBS, (2019). Yearbook of Agricultural Statistics-2018.Bangladesh Bureau of Statistics, Ministry of Planning Government of the People's Republic of Bangladesh.

BBS, (2017). Yearbook of Agricultural Statistics-2016. Bangladesh Bureau of Statistics, Ministry of Planning Government of the People's Republic of Bangladesh.

BBS, (2014). Yearbook of Agricultural Statistics-2013. Bangladesh Bureau of Statistics, Ministry of Planning Government of the People's Republic of Bangladesh.

BBS, (2012). Yearbook of Agricultural Statistics-2011. Bangladesh Bureau of Statistics, Ministry of Planning Government of the People's Republic of Bangladesh.

Bhagawati, K., Bhagawati, G., Das, R., Bhagawati, R. and Ngachan, S.V. (2015). The structure of Jhum (Traditional Shifting Cultivation System): prospect or threat to climate. International Letters of Natural Sciences, 46. 16-30.

Chakma, A. S. and Nahar, B. S. (2012). Jhum Cultivation Influence the Degradation of Hilly Environment. Journal of Environmental Science and Natural Resources, 5(2), 339-344.

Chakma, S. (2008). Turmeric cultivation thrives in CHT. (Accessed 02 June, 2020). Available: https://www.thedailystar.net/news-detail-60935

Chakma, S. S. and Ando, K. (2008). Jhum cultivation in Khagrachari hill district of Bangladesha subsistence farming practices in ethnic minorities. $J$ Agroforestry and Environment, 2(2), 1-8.

Dewan, B., Sarkar, F., and Alam, M. N. (2015). Scenario of Major Fruits Production and Marketing System in Chittagong Hill Tracts Study Based on Khagrachari Hill District, Bangladesh. International Journal of Economics, Commerce and Management, 3(5), 966-977.

Hossain, M. A. (2011). An overview on shifting cultivation with reference to Bangladesh. Scientific Research and Essays, 6(31), 6509-6514.

Hossain, M. A., and Ahmad, A. (2017). Livelihood status of hill dwellers in Bandarban, Bangladesh. International Journal of Business, Management and Social Research, 03(1), 154-161.

Hossain, M. A., Jashimuddin, M., Nath, T. K. and O'Reilly, P. (2017). Spiny coriander (Eryngium foetidum L.) cultivation in the Chittagong Hill Tracts of Bangladesh: 
International Journal of Agriculture and Environmental Research

ISSN: 2455-6939

Volume: 06, Issue: 05 "September-October 2020"

Sustainable agricultural innovation by indigenous communities. Indian Journal of Traditional Knowledge 16(1), 59-67.

Islam, M. S., Tapan, M. Z., and Nayan, T. B. (2010). Fact sheet: tobacco farming impact from peoples' perspective. Unnayan Dhara, Bangladesh.

Jamaluddin, M., Hassan, M. K., and Miah, M. M. (2010). Identifying livelihood patterns of ethnic minorities and their coping strategies different vulnerabilities situation in Chittagong hill tracts region, Bangladesh. Final Report CF, 7(08).

Karim, S. R. and Mansor, M. (2011). Impact of jhum cultivation on the Agro-ecology of Mountains and Socio-economy of Tribal Peoples. Asian Journal of Agricultural Research, 5(2), 109-114.

Khan, A. S. M. M. R., and Alam, M. R. (2015). Technological advancement in agro-forestry systems: strategy for climate smart agricultural technologies in Bangladesh. In (eds) Technological advancement in agro-forestry systems: Strategy for climate smart agricultural technologies in SAARC Region. Gurung, T. R., and Temphel, K. J., p53-97.

Khan, M. H., Aziz, M. A., Uddin, M., Sharif, S., Chowdhury, S. U., Chakma, S., Chowdhury, G. W., Jahan, I., Akter, R., Myant, M. H., and Mohsanin, S. (2012). Community conserved areas in Chittagong Hill Tracts of Bangladesh. In Islam, MA, ed. Wildlife Trust of Bangladesh, Dhaka, Bangladesh.

Khisa, S. K., and Mohiuddin, M. (2015). Shrinking jhum and changing livelihoods in the Chittagong Hill Tracts of Bangladesh. Shifting cultivation, livelihood and food security, p41.

Kibria, A. S. M. G., Inoue, M. and Nath, T. K., (2015). Analysing the land uses of forestdwelling indigenous people in the Chittagong Hill Tracts, Bangladesh. Agroforestry systems, 89(4), 663-676.

Mahmud, S., Alam, M. R., Amin, M., and Hassan, M. M. (2018). Performances of improved and traditional rice based jhum cultivation in a hill district of Bangladesh. Journal of the Bangladesh Agricultural University, 16(2), 193-197.

Misbahuzzaman, K. (2016). Traditional farming in the mountainous region of Bangladesh and its modifications. Journal of Mountain Science, 13(8), 1489-1502.

Motaleb, M. A., and Irfanullah, H. M. (2011). Tobacco cultivation in Bangladesh: is it a threat to traditional agro-practice? Indian Journal of Traditional Knowledge, 10 (3), 481-485. 
International Journal of Agriculture and Environmental Research

ISSN: 2455-6939

Volume: 06, Issue: 05 "September-October 2020"

Nath, T. K., Jashimuddin, M., and Inoue, M. (2016a). Community Participation in Agroforestry Development: Lessons Learned from a Collaborative Research Project. In CommunityBased Forest Management (CBFM) in Bangladesh, pp. 125-154, Springer.

Nath, T. K., Jashimuddin, M., Hasan, M. K., Shahjahan, M., and Pretty, J., (2016b). The sustainable intensification of agroforestry in shifting cultivation areas of Bangladesh. Agroforestry Systems, 90(3), 405-416.

Nathan, D., Bala, B. K. and Siddiqi, Y. (2013). A Proposed Strategy for Agricultural Development.

(https://www.cabi.org/Uploads/CABI/OpenResources/91797/Finished\%20A9\%20Nathan $\% 20$ And\%20Bala.pdf)

Olarieta, J. R., Rodriguez-Ochoa, R., and Ascaso, E. (2007). Land management practice in Chittagong hill tracts and sustainable alternatives. CHARM Project report 4.

Paul, S. P., and Hossain, A. T. M. E. (2001). Agroforestry research and development in the hill region of Bangladesh: experiences, problems and research needs. Proceedings of the National Workshop on "Agroforestry Research and Development in Bangladesh", BARI, Gazipur.

Quais, M. K., Rashid, M. H., Shahidullah, S. M. and Nasim, M. (2017). Crops and Cropping Sequences in Chittagong Hill Tracts. Bangladesh Rice Journal, 21(2), 173-184.

Rahman, S. A., Rahman, M. F. and Sunderland, T. (2014). Increasing tree cover in degrading landscapes: 'Integration' and 'Intensification' of smallholder forest culture in the Alutilla valley, Matiranga, Bangladesh. Small-scale Forestry, 13(2), 237-249.

Rahman, S. A., Rahman, M. F., and Sunderland, T. (2012). Causes and consequences of shifting cultivation and its alternative in the hill tracts of eastern Bangladesh. Agroforestry systems, 84(2), 141-155.

Rasul, G., Thapa, G. B., and Zoebisch, M. A. (2004). Determinants of land-use changes in the Chittagong Hill Tracts of Bangladesh. Applied geography, 24(3), 217-240.

Rasul, G., (2009). Ecosystem services and agricultural land-use practices: a case study of the Chittagong Hill Tracts of Bangladesh. Sustainability: Science, Practice and Policy, 5(2), $15-27$. 
Volume: 06, Issue: 05 "September-October 2020"

Rasul, G., and Tripura, N. B. K. (2016) Achieving the sustainable development goals in Chittagong Hill Tracts-Challenges and opportunities. ICIMOD Working Paper 2016/12. Kathmandu: ICIMOD.

Shoaib, J. U., Mostafa, G., and Rahman, M. (1998). A Case Study on Soil Erosion Hazard in Hilly Regions of Bangladesh, Annual Report, Soil Resource Development Institute, Dhaka.

SRDI, (2018). Annual Report 2017-18. Soil Resource Development Institute, Ministry of Agriculture, Government of the People's Republic of Bangladesh, Dhaka.

The Dhaka Tribune. (2014). Ginger-turmeric cultivation in hills brings solvency to farmers. (Accessed $05 \quad$ June, 2020). Available: https://www.dhakatribune.com/uncategorized/2014/08/24/ginger-turmeric-cultivation-inhills-brings-solvency-to-farmers

Ullah, M. S., and Shamsuddoha, M. (2014). The viability of the Chittagong Hill Tracts as a destination for climate-displaced communities in Bangladesh. In Land Solutions for Climate Displacement, Routledge. pp 215-247.

Zakaria, A. F. M. and Majumder, N. M. (2019). Are Khasis of Bangladesh Eco-Friendly Agro Manager? Reflections on Hill Farming Practices and Forest Conservation. Journal of Science, Technology and Environment Informatics, 8(1), 574-582. 